Hiroshi Kawame • Yoko Sugio • Yuichi Fuyama

Yoshihiro Hayashi · Hideaki Suzuki • Kenji Kurosawa

Kihei Maekawa

\title{
Syndrome of microcephaly, Dandy-Walker malformation, and Wilms tumor caused by mosaic variegated aneuploidy with premature centromere division (PCD): report of a new case and review of the literature
}

\begin{abstract}
We report a male infant with multiple congenital anomalies and mosaic variegated aneuploidy; a rare cytogenetic abnormality characterized by mosaicism for several different aneuploidies involving many different chromosomes. He had prenatal-onset growth retardation, microcephaly, dysmorphic face, seizures, hypotonia, feeding difficulty, and developmental delay. In addition, he developed bilateral Wilms tumors. Neuroradiological examination revealed Dandy-Walker malformation and hypoplasia of the cerebral hemisphere and pons. Cytogenetic analysis revealed various multiple numerical aneuploidies in blood lymphocytes, fibroblasts, and bone marrow cells, together with premature centromere division (PCD). Peripheral blood chromosome analysis from his parents also showed PCD, but no aneuploid cells. The clinical phenotype and multiple aneuploidies of the patient may be a consequence of the homozygous PCD trait inherited from his parents. Comparison with previously reported cases of multiple aneuploidy suggests that mosaic variegated aneuploidy with PCD may be a clinically recognizable syndrome with major phenotypes being mental retardation, microcephaly, structural brain anomalies (including DandyWalker malformation), and possible cancer predisposition.
\end{abstract}

Key words Mosaic variegated aneuploidy - Microcephaly · Dandy-Walker malformation - Wilms tumor - Premature centromere division

H. Kawame $(\bowtie) \cdot$ K. Kurosawa

Department of Pediatrics, Tokyo Metropolitan Kita Medical and

Rehabilitation Center, 1-2-3 Jujodai, Kita-ku, Tokyo 114-0033, Japan Tel. +81-3-3908-3001; Fax +81-3-3908-2984

e-mail: hkawame@yk.rim.or.jp

H. Kawame · Y. Fuyama · Y. Hayashi · H. Suzuki · K. Maekawa Department of Pediatrics, Jikei University School of Medicine,

Tokyo, Japan

Y. Sugio

Department of Pediatrics, Yamaguchi Prefectural Central Hospital, Yamaguchi, Japan

Received: January 21, 1999 / Accepted: February 26, 1999

\section{Introduction}

Multiple aneuploidy is a rare cytogenetic abnormality characterized by mosaicism for several different aneuploidies involving many different chromosomes. Since the multiple congenital anomalies/mental retardation syndrome associated with this cytogenetic phenomenon was first reported by Scheres et al. (1986), to date, only several patients have been reported (Tolmie et al. 1988; Papi et al. 1989; Miller et al. 1990; Warburton et al. 1991; Limwongse et al. 1997; Nash et al. 1997; Flejter et al. 1998; Kajii et al. 1998). Clinical features in the reported patients were variable, but growth retardation and microcephaly were frequently described. Warburton et al. (1991) proposed the term "mosaic variegated aneuploidy with microcephaly" for this syndrome. Although it was suggested that this syndrome may represent a human mitotic mutant, the etiology of the various aneuploidies involving different chromosomes has not been understood.

In some patients, premature centromere division (PCD) was associated with numerical aneuploidies (Scheres et al. 1986; Miller et al. 1990; Warburton et al. 1991; Limwonge et al. 1997; Kajii et al. 1998). PCD is a cytogenetic phenomenon characterized by parallel separated rod-like sister chromatids in metaphase. In the literature there is confusion between PCD and a similar, but distinct, cytogenetic phenomenon: the RS effect. This cytogenetic abnormality has been described as Roberts-SC syndrome (Parry et al. 1986). This phenomenon is characterized by splitting and puffing at the centromere region, and is different from PCD. Furthermore, PCD of the X chromosome only in normal women, which is a relatively common finding in aged populations, is also a distinct entity (Fitzgerald 1975).

We report a further case of this rare cytogenetic phenomenon and multiple congenital anomalies. The patient had prenatal-onset growth retardation, developmental delay, minor facial features, microcephaly, Dandy-Walker malformation without hydrocephalus, and bilateral Wilms tumors. Cytogenetic analysis of both phenotypically normal parents revealed PCD, but no aneuploidy. The clinical and 
cytogenetic findings in our patient were compared with those of previously reported patients.

\section{Clinical Report}

The patient was a 19-month-old male infant who was the first child of a 27 -year-old mother and a 25 -year-old father. The parents were in good health and non-consanguineous. The family history was unremarkable. The pregnancy was uneventful until 20 weeks of gestation, when fetal growth retardation was first detected by ultrasound examination. At the follow-up examination at 28 weeks of gestation, dilation of the ventricle of the fetal brain and fetal ascites were noted. At 31 weeks, due to fetal growth retardation and the presence of brain anomalies, amniocentesis was done. Chromosome analysis of amniocytes was mosaicism of $48, \mathrm{XY},+7,+19[6] / 46, \mathrm{XY}[9]$. At 37 weeks of gestation, the infant was delivered by cesarean section. Apgar scores were 8 and 9 at 1 and $5 \mathrm{~min}$, respectively. His birth weight was $1748 \mathrm{~g}(-2.5 \mathrm{SD})$; birth length, $39.5 \mathrm{~cm}(-3.9 \mathrm{SD})$; and occipitofrontal circumstances (OFC), $27.8 \mathrm{~cm}(-2.9 \mathrm{SD})$.

On examination, his craniofacial findings were remarkable, with severe microcephaly and dysmorphic facial features (Fig. 1). The anterior and posterior fontanelles were both closed. The hair was mildly fair. There was no scalp defect. There was ocular hypertelorism, exophthalmos, and epicanthic folds. The nasal bridge was broad and prominent. The nasal tip was up-turned. The ears were low-set, posteriorly rotated, and dysplastic. The neck was short and broad, and there was excess skin on the posterior part of the neck. The chest was normal and no murmur was detected. The abdomen was unremarkable. There was hypospadias and bilateral cryptorchidism. The hands were normal. The feet were long and bilateral plantar creases were noted. The toes were normal. There were no birthmarks, including hemangioma. Neurologically, there was severe hypotonia. Moro reflex was weak.
Ultrasound examination of his brain indicated a large cystic region in the posterior fossa, and hypoplasia of the corpus callosum. Subsequent cranial computed tomography (CT) scan and magnetic resonance imaging (MRI) examinations showed Dandy-Walker malformation without hydrocephalus, partial agenesis of the corpus callosum, and hypoplasia of the cerebral hemisphere and pons (Fig. 2). Ophthalmologic examination revealed coloboma of the choroid, bilateral cataracts, and corneal clouding. Echocardiogram was normal. Ultrasound and CT of abdomen showed no renal abnormalities.

At the age of 7 days he developed seizures. Usually the seizures began with spasms of the eyelids and developed to clonic seizures of the upper extremities associated with apnea. The seizures were intractable, with many antiepileptic drugs having been administered. At age 2 months, a nasogastric tube was placed due to the frequent seizures and poor sucking. His weight was $2346 \mathrm{~g}(-3.7 \mathrm{SD})$, length, $42 \mathrm{~cm}(-5.9 \mathrm{SD})$, OFC $31 \mathrm{~cm}(-4.5 \mathrm{SD})$.

At the age of 7 months, he was noted to have a palpable left abdominal mass. CT scan of the abdomen revealed heterogeneous cystic renal masses in both kidneys. The left renal mass increased in size and he developed hypertension, dyspnea, and poor sucking. At the age of 10 months, left nephrectomy and right tumor excision were performed. The results of a pathological evaluation showed Wilms tumors (nephroblastoma type). He received postoperative chemotherapy and radiation.

At the age of 19 months, his weight was $9920 \mathrm{~g}(-0.75 \mathrm{SD})$; length, $68 \mathrm{~cm}(-4.45 \mathrm{SD})$; and OFC $43 \mathrm{~cm}(-3.0 \mathrm{SD})$. He smiled socially, and responded to sound, but he had no head control.

\section{Cytogenetics}

Chromosome analysis of lymphocyte culture was performed by a phytohemagglutinin (PHA) -stimulated routine proce-

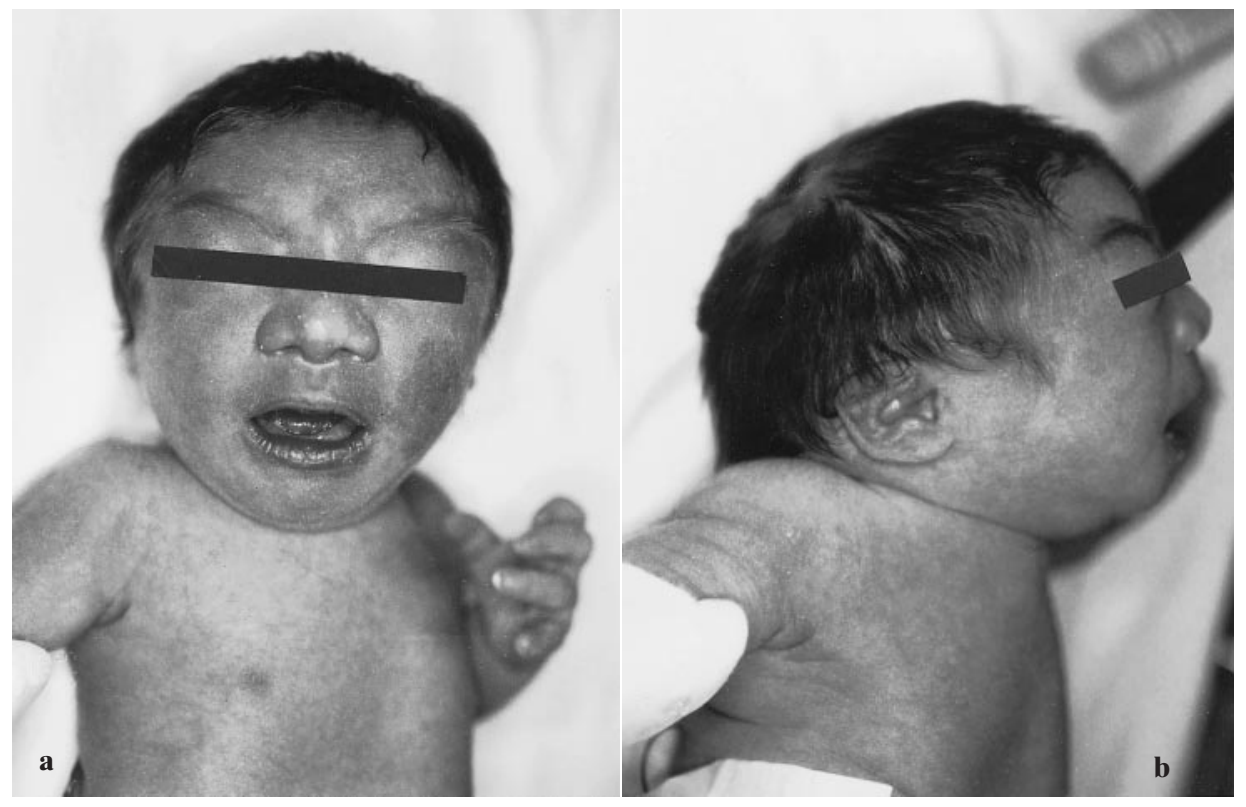

Fig. 1. Facial aspect of the patient at age 2 days 


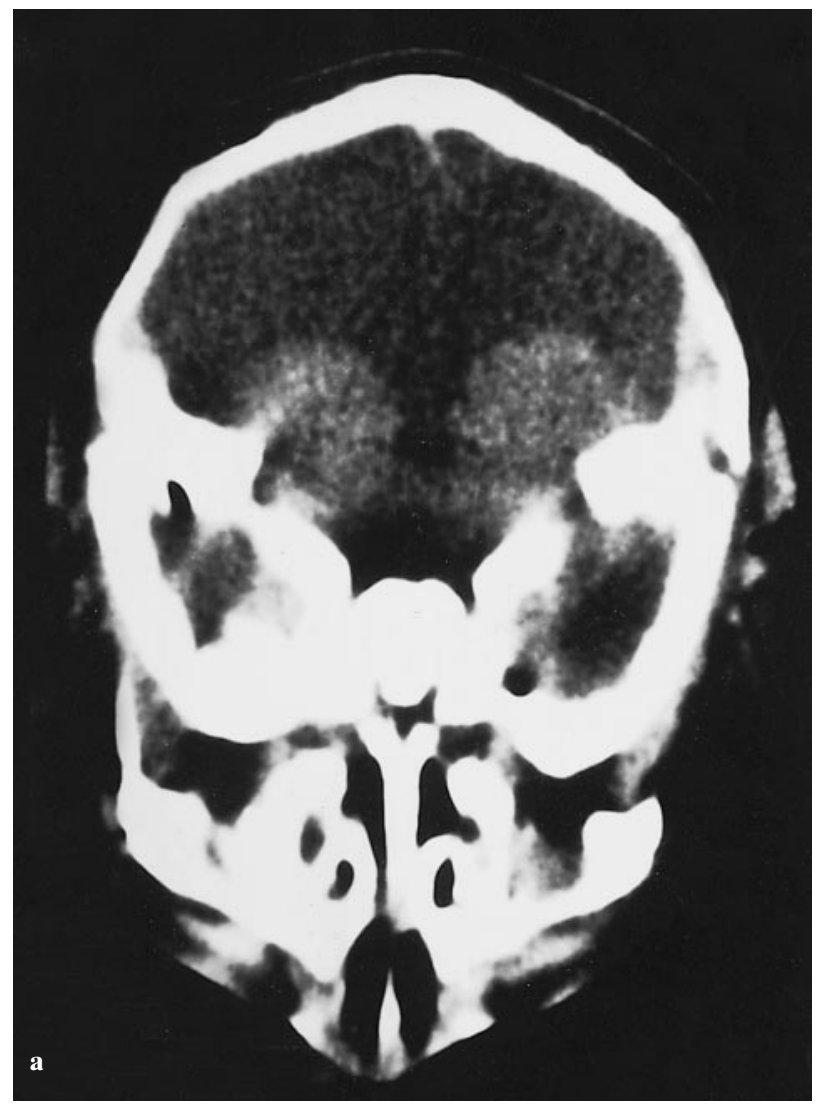

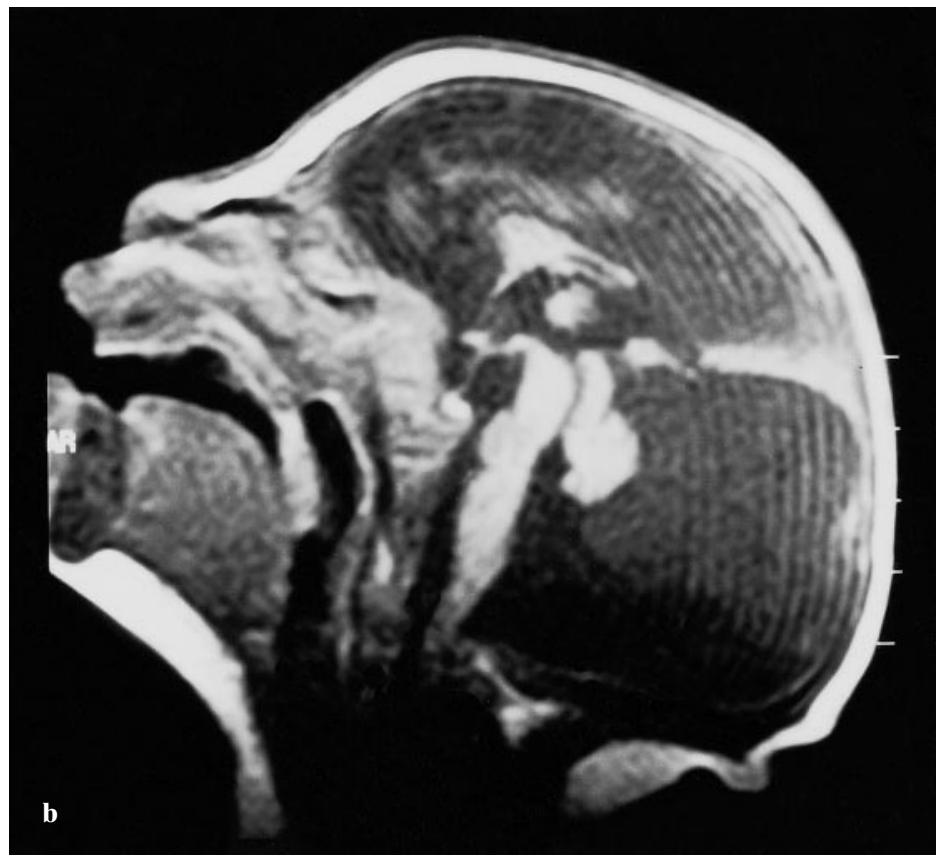

Fig. 2. a Axial computed tomography scan of the posterior fossa shows dilatation of the fourth ventricle and hypoplasia of the cerebellar vermis, which is consistent with Dandy-Walker malformation. b Sagittal magnetic resonance image showed partial agenesis of the corpus callosum, and hypoplasia of the cerebral hemisphere and pons

Table 1. Distribution of aneuploid cells in various tissues

\begin{tabular}{lllllllll}
\hline & & & \multicolumn{2}{c}{ Total chromosome number in metaphase cells } \\
\cline { 5 - 7 } Tissue & Total cells & Normal 46, XY & 45 & 46 & 47 & 48 & 49 & Aneuploid cells (\%) \\
\hline Cord blood & 77 & 50 & 6 & 4 & 13 & 1 & 3 & 35 \\
Peripheral blood & 111 & 92 & 1 & 2 & 13 & 2 & 1 & 17 \\
Fibroblasts & 34 & 26 & 2 & 0 & 4 & 2 & 0 & 24 \\
Bone marrow & 19 & 17 & 1 & 0 & 1 & 0 & 0 & 11 \\
\hline
\end{tabular}

dure with colcemid $(0.1 \mu \mathrm{g} / \mathrm{ml}, 75 \mathrm{~min})$. The results of cord blood chromosome analysis showed multiple numerical aneuploidies involving many different chromosomes (Table 1). Chromosome analysis of peripheral blood taken at age 1 day also showed multiple aneuploidies with a different distribution of aneuploid cells from that observed in the cord blood. Although numerical aneuploidy was not detected for all chromosomes, aneuploid chromosomes were variable. Among various aneuploid cells, trisomy 8 was most common ( 7 of 19 metaphase cells) in peripheral blood lymphocytes. Trisomy 22, gain of the Y chromosome (47, XYY), and trisomy 8 were relatively common in the cord blood cells, being identified in 4, 3 , and 2 metaphase cells, respectively, of a total 27 aneuploid cells. Results of chromosomal analysis of peripheral blood at age 15 days were similar (data not shown).

Chromosome analysis of cultured fibroblasts established from a skin biopsy done at age 20 days showed similar aneuploidy. Bone marrow cells taken at age 4 months were directly analyzed after colcemid treatment. The chromosomes of uncultured bone marrow cells also showed mul- tiple aneuploid cells, such as monosomy 7 and trisomy 6 .

Premature centromere division (PCD) was analyzed by the Center for Molecular Biology and Cytogenetics, SRL Laboratory (Tokyo, Japan). PCD was found in all chromosomes in $82 \%$ of 200 cells from peripheral blood lymphocyte cultures. (Fig. 3). After genetic counseling and obtaining informed consent, peripheral blood chromosome analyses from the parents were performed. Both showed $\mathrm{PCD}$, in $42.5 \%$ of 200 cells from the mother and in $5 \%$ of 200 cells from the father. The control rate of PCD is less than $2 \%$ of cells (Kajii et al. 1998). No aneuploid cells in 20 metaphases were detected in either parent.

\section{Discussion}

We report here a patient with multiple congenital anomalies/ mental retardation syndrome with a rare cytogenetic phenomenon, i.e., various multiple numerical aneuploidies in 
Table 2. Clinical and cytogenetic findings of patients with multiple mosaic aneuploidies

\begin{tabular}{|c|c|c|c|c|c|c|c|}
\hline Case no. & Present patient & 1 & 2 & (Siblings) & 3 & (Siblings) & 4 \\
\hline Sex & M & $\mathrm{F}$ & $\mathrm{F}$ & M & M & $\mathrm{F}$ & M \\
\hline Age & 19 Months & 29 Years & 2 Years & 3 Months & 33 Years & 24 Years & 8 Months \\
\hline Height & $-4.45 \mathrm{SD}$ & & $-3 \mathrm{SD}$ & & $<3$ rd Centile & $<3$ rd Centile & $<3$ rd Centile \\
\hline Weight & $-0.75 \mathrm{SD}$ & & $-5 \mathrm{SD}$ & & & & $<3$ rd Centile \\
\hline OFC & $-3.0 \mathrm{SD}$ & & $-13 \mathrm{SD}$ & & & & $<2$ nd Centile \\
\hline \multicolumn{8}{|l|}{ Family history } \\
\hline Consanguinity & - & & - & & + & & - \\
\hline Perinatal history & IUGR & & IUGR & & & & IUGR \\
\hline Gestational week (weeks) & 37 & & 37 & 40 & 40 & & 37 \\
\hline Mother's age (years) & 27 & & 30 & & & & 24 \\
\hline Father's age (years) & 24 & & 33 & & & & 29 \\
\hline Birth weight & $-2.5 \mathrm{SD}$ & & 10th-25th Centile & $<10$ th Centile & & & $<10$ th Centile \\
\hline Birth length & $-3.9 \mathrm{SD}$ & & & & & & $<10$ th Centile \\
\hline Birth OFC & $-2.9 \mathrm{SD}$ & & $<10$ th Centile & $<10$ th Centile & & & $<10$ th Centile \\
\hline Microcephaly & + & + & + & + & + & + & + \\
\hline \multicolumn{8}{|l|}{ Face } \\
\hline Epicanthus & + & & + & & & & + \\
\hline Prominent nasal root & + & & & & & & \\
\hline Micrognathia & + & & + & & + & + & \\
\hline Other & $\begin{array}{l}\text { Hypertelorism; } \\
\text { exophthalmos }\end{array}$ & & $\begin{array}{l}\text { Occipital } \\
\text { prominence }\end{array}$ & & $\begin{array}{l}\text { High-arched } \\
\text { palate }\end{array}$ & $\begin{array}{l}\text { High-arched } \\
\text { palate }\end{array}$ & $\begin{array}{l}\text { Low-set ears; } \\
\text { coarse face }\end{array}$ \\
\hline Skin findings & & & Nevus flammeus & & & Hemangioma & Hemangioma \\
\hline Growth retardation & + & & + & + & + & + & \\
\hline Neurologic features & & & & & & & + \\
\hline Developmental delay/MR & + & + & + & & + & + & \\
\hline Seizure & + & & + & & + & + & + \\
\hline Other findings & $\begin{array}{l}\text { Cystic hygroma; } \\
\text { corneal opacity; } \\
\text { coloboma of } \\
\text { choroid; } \\
\text { hypospadias; } \\
\text { cryptorchidism; } \\
\text { DWM, Wilms } \\
\text { tumor }\end{array}$ & Amenorrhea & $\begin{array}{l}\text { Pectus carinatum; } \\
\text { kyphoscoliosis; } \\
\text { hip dislocation }\end{array}$ & & $\begin{array}{l}\text { Muscular } \\
\text { dystrophy }\end{array}$ & & $\begin{array}{l}\text { Combined } \\
\text { immunodeficiency }\end{array}$ \\
\hline \multicolumn{8}{|l|}{ Cytogenetic findings } \\
\hline \multicolumn{8}{|l|}{ Aneuploidy } \\
\hline Lymphocytes & $17 \%$ & $15 \%$ & $35 \%-84 \%$ & $28 \%-43 \%$ & $15 \%$ & $20 \%$ & $70 \%$ \\
\hline Fibroblasts & $24 \%$ & $\mathrm{nl}$ & $28 \%$ & $\mathrm{nl}$ & $26 \%$ & $24 \%$ & $\begin{array}{l}\text { Similar to } \\
\text { lymphocytes }\end{array}$ \\
\hline PCD & $82 \%$ & $60 \%$ & ND & ND & ND & ND & $39 \%-51 \%$ \\
\hline Parental cytogenetic findings & PCD & PCD & $\mathrm{nl}$ & & $\begin{array}{c}\text { aneuploidy } \\
(4-8 \%)\end{array}$ & & $\mathrm{nl}$ \\
\hline
\end{tabular}

Blank, Information was not available; ND, not detected; nl, normal; OFC, occipitofrontal circumference; PCD, premature centromere division; IUGR,

intrauterine growth retardation; CALS, café-au-lait spot; MR, mental retardation; DWM, Dandy-Walker malformation; patients 1, Sheres et al; 2, Tolmie et al.; 3,

Papi et al.; 4, Miller et al.; 5, Warburton et al.; 6, Limwongse et al.; 7, Nash et al.; 8, Flejter et al.; 9 and 10, Kajii et al.

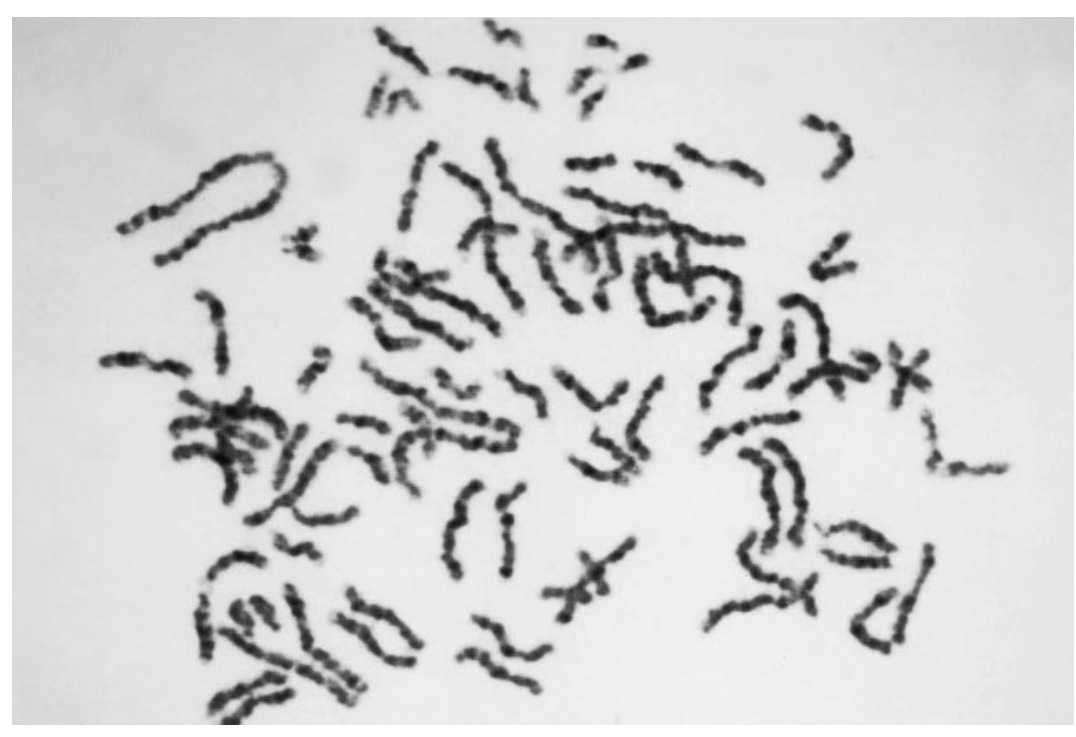

Fig. 3. Premature centromere division was found in all chromosomes in $82 \%$ of 200 cells from lymphocyte cultures 


\begin{tabular}{|c|c|c|c|c|c|c|}
\hline 5 & 6 & 7 (Siblings) & 8 & (Siblings) & 9 & 10 \\
\hline $\begin{array}{l}\mathrm{F} \\
17 \text { Years } \\
-3 \mathrm{SD} \\
-10 \mathrm{SD}\end{array}$ & $\begin{array}{l}\text { M } \\
7 \text { Years }\end{array}$ & $\begin{array}{l}\text { F } \\
4 \text { Months }\end{array}$ & $\begin{array}{l}\mathrm{F} \\
5 \text { Years } \\
<5 \text { th Centile } \\
<5 \text { th Centile } \\
\text { 2nd Centile }\end{array}$ & $\begin{array}{l}\mathrm{F} \\
24 \text { Months } \\
<5 \text { th Centile } \\
<5 \text { th Centile } \\
<\text { 2nd Centile }\end{array}$ & $\begin{array}{l}\text { F } \\
18 \text { Months }\end{array}$ & $\begin{array}{l}\text { M } \\
7 \text { Months } \\
-5.5 \mathrm{SD} \\
-7.8 \mathrm{SD} \\
-8.2 \mathrm{SD}\end{array}$ \\
\hline - & UUGR & UUGR & - & & - & - \\
\hline $\begin{array}{l}28 \\
28\end{array}$ & 33 & 32 & 40 & $38-39$ & $\begin{array}{l}37 \\
26 \\
26 \\
-3.6 \mathrm{SD} \\
-5.1 \mathrm{SD} \\
-5.5 \mathrm{SD}\end{array}$ & $\begin{array}{l}40 \\
30 \\
37 \\
-4.7 \mathrm{SD} \\
-11.4 \mathrm{SD} \\
-6.7 \mathrm{SD}\end{array}$ \\
\hline+ & + & & + & + & + & + \\
\hline+ & & & $\begin{array}{l}- \\
+\end{array}$ & $\begin{array}{l}- \\
+\end{array}$ & $\begin{array}{l}- \\
-\end{array}$ & $\begin{array}{l}- \\
-\end{array}$ \\
\hline+ & $\begin{array}{l}\text { Upturned nasal tip; } \\
\text { smooth philtrum }\end{array}$ & + & + & + & $\begin{array}{l}- \\
\text { Midface } \\
\text { hypoplasia; } \\
\text { low-set ears }\end{array}$ & $\stackrel{+}{\text { Low-set ears }}$ \\
\hline $\begin{array}{l}\text { Atopic } \\
\text { dermatitis }\end{array}$ & + & + & $\begin{array}{l}\text { Hypo/hyperpigmentation; } \\
\text { CALS } \\
+\end{array}$ & $\begin{array}{l}\text { Hypo/hyperpigmentation; } \\
\text { CALS } \\
+\end{array}$ & $\begin{array}{l}- \\
+\end{array}$ & $\begin{array}{l}- \\
+\end{array}$ \\
\hline+ & - & & - & - & $\begin{array}{l}+ \\
+\end{array}$ & + \\
\hline & $\begin{array}{l}\text { Rhabdomyosarcoma; } \\
\text { crytptorchidism; } \\
\text { clinodactyly }\end{array}$ & $\begin{array}{l}\text { Pulmonary stenosis; } \\
\text { corneal opacity; } \\
\text { glaucoma }\end{array}$ & Clinodactyly & Clinodactyly & $\begin{array}{l}\text { Cataracts; } \\
\text { cleft palate; } \\
\text { Wilms tumor; } \\
\text { DWM }\end{array}$ & $\begin{array}{l}\text { Cataracts; } \\
\text { short neck; } \\
\text { genital } \\
\text { anomalies; } \\
\text { DWM; } \\
\text { oligogyria }\end{array}$ \\
\hline $\begin{array}{l}6 \%-20 \% \\
8 \%-42 \%\end{array}$ & $\begin{array}{l}33 \% \\
\mathrm{nl}\end{array}$ & $\begin{array}{l}83 \% \\
+\end{array}$ & $8 \%$ & $19 \%$ & $\begin{array}{l}15 \%-20 \% \\
92 \%\end{array}$ & $7 \%-15 \%$ \\
\hline+ & + & $\mathrm{nl}$ & $\begin{array}{l}\mathrm{ND} \\
\mathrm{nl}\end{array}$ & ND & $\begin{array}{l}21 \%-86.5 \% \\
\text { PCD }\end{array}$ & $\begin{array}{l}84 \%-87.5 \% \\
\text { PCD }\end{array}$ \\
\hline
\end{tabular}

different tissues. To our knowledge, only thirteen cases, including four sib pairs, have been reported in the literature (Table 2). There was marked phenotypic variability among these patients, but their main clinical features were prenatalonset growth retardation and microcephaly. Microcephaly was noted in the most patients (13/14, including our patient). However, structural brain anomalies associated with microcephaly were rarely described. Our patient had dilatation of the fourth ventricle and hypoplasia of the cerebellar vermis, features which were consistent with Dandy-Walker malformation. This anomaly was also seen in the patients described by Kajii et al. (1998). Although the etiological relationship between Dandy-Walker malformation and multiple aneuploidies was not clear, these structural brain anomalies are most likely features of this syndrome, together with the findings reported by Kajii et al. (1998). The detailed facial features were not fully described in all reported patients. The only common facial feature reported was micrognathia. It is, at present, uncertain whether there are identifiable facial features specific for this condition.

While there were several common clinical and cytogenetic features, it is unclear whether all reported patients had the same etiological defects and whether the same mechanism was responsible for the development of phenotypes. Presumably, the primary defect could be a genetic defect of chromosomal segregation in cell mitosis, or mitotic checkpoint failure. Flejter et al. (1998) analyzed metaphase cells from their patients by immunofluoresence with antibodies to kinetochore-specific protein CENP-E, but the results showed normal staining and suggested that chromosomes contained functional, active centromeres. Recently, mutations of the mitotic checkpoint gene, $h B U B 1$, were detected in human colorectal cancer cells which showed chromosomal instability and aneuploidy (Cahill et al. 1998). Thus, cell cycle checkpoint genes may be responsible for this genetic abnormality. Of note, three patients, including our patient, developed can- 
cers (rhabdomyosarcoma and Wilms tumor) (Limwongse et al. 1997, Kajii et al. 1998). These findings indicate that patients with this syndrome are predisposed to develop cancers, and physicians must be aware of this association.

Because of the high percentage of actively dividing cells present in the bone marrow, cytogenetic analysis can be performed on this tissue without introducing possible artifacts that occur in cultured cells. The presence of aneuploid cells in the bone marrow from our patient agrees with similar findings by Warburton et al. (1991); aneuploid cells must be in vivo. In terms of phenotype development, multiple random numerical aneuploidies resulting from mitotic abnormality could affect the normal sequence of development of certain organs and result in this syndrome.

PCD (OMIM 176430) is a cytogenetic phenomenon characterized by parallel separated rod-like sister chromatids in metaphase. PCD itself has been shown to segregate in autosomal dominant inheritance in some families (Rudd et al. 1983; Madan et al. 1987). Individuals with PCD were usually clinically normal, but there was sometimes an association with multiple spontaneous abortions or sterility (Rudd et al. 1983; Gabarron et al. 1986). Fitzgerald et al. (1986) reported a clinically normal woman with three conceptuses with trisomy 21 who had PCD in some chromosomes. It was proposed that PCD may result in aneuploid cell lines because prematurely separated centromeres apparently cannot attach to the spindle fibers and this produces non-disjunction. PCD was observed in six patients with multiple mosaic anuploidies (see Table 2). The degree of PCD in these patients varied and may not be comparable, because of differences in methods for determination and differences in definitions of PCD. Among these six patients, PCD was observed in the parents of the patients described by Scheres et al. (1986) and Kajii et al. (1998). Together with findings in our patient, these findings strongly suggest that the probands were likely to have inherited the PCD trait from both parents and to have had severe PCD, which resulted in the multiple various aneuploidies. In terms of the PCD trait, the proband was homozygous for an autosomal dominant PCD trait. On the other hand, there was evidence of consanguinity in the family described by Papi et al. (1989) and multiple sibling cases were described in some families without PCD; thus, autosomal recessive inheritance is likely for those families and this indicates genetic heterogeneity for this rare cytogenetic syndrome.

Because the phenotypes, cytogenetic findings, and inheritance in the reported patients are variable, the mechanism for multiple mosaic aneuploidies could be heterogeneous. Further biochemical or molecular investigations of the control of cell mitosis and chromosomal segregation may provide information to show whether these cases represent a single genetic syndrome. However, comparison of our patients' features with those of previously reported patients suggests that mosaic variegated aneuploidy associated with PCD may be a clinically recognizable syndrome, phenotypes being microcephaly, mental retardation, and structural brain anomalies, including Dandy-Walker malformation.

Clinicians should be aware of this rare syndrome and bear it in mind when encountering ambiguous amniocyte chromosomes suggestive of placental mosaicism, and genetic counseling should be provided for families with PCD.

Acknowledgments We are grateful to Dr T. Watanabe, at the Genetic Laboratory, Jikei University Hospital, for cytological investigation, and we thank the SRL Laboratory, Tokyo, for analysis for PCD. We also thank Dr Kathleen Leppig, at the Division of Medical Genetics, Children's Hospital and Medical Center, Seattle, for critical reading of the manuscript.

\section{References}

Cahill DP, Lengauer C, Yu J, Riggins GJ, Willson JKV, Markowitz SD, Kinzler KW, Vogelstein B (1998) Mutation of mitotic checkpoint genes in human cancers. Nature 392:300-303

Fitzgerald PH (1975) A mechanism of X chromosome aneuploidy in lymphocytes of aging women. Hum Genet 28:153-158

Fitzgerald PH, Archer SA, Morris CM (1986) Evidence for the repeated primary non-disjunction of chromosome 21 as a result of premature centromere division (PCD). Hum Genet 72:58-62

Flejter WL, Issa B, Sullivan BA, Carey JC, Brothman AR (1998) Variegated aneupolidy in two siblings: Phenotype, genotype, CENP$\mathrm{E}$ analysis, and literature review. Am J Med Genet 75:45-51

Gabarron J, Jimenez A, Glover G (1986) Premature centromere division dominantly inherited in a subfertile family. Cytogenet Cell Genet 43:69-71

Kajii T, Kawai T, Takumi T, Misu H, Mabuchi O, Takahashi Y, Tachino M, Nihei F, Ikeuchi T (1998) Mosaic variegated aneuploidy with multiple congenital abnormalities: Homozygous for total premature chromatid separation trait. Am J Med Genet 78:245-249

Limwongse C, Robin NH, Schwartz S (1997) Mosaic variegated aneuploidy: Another cytogenetic anomaly with increased cancer risk? Am J Hum Genet 61:A105

Madan K, Lindhout D, Palan A (1987) Premature centromere division (PCD): a dominantly inherited cytogenetic anomaly. Hum Genet 77:193-196

Miller K, Muller W, Winkler L, Hadam MR, Ehrich JH, Flatz SD (1990) Mitotic disturbance associated with mosaic aneuploidies. Hum Genet 84:361-364

Nash RN, Willatt LR, Andrew TA, Green AJ (1997) Recurrent multiple aneuploidies:a family with autosomal recessive failure of mitotic control. Am J Hum Genet 61:A136

Papi L, Montali E, Marconi G, Guazzelli R, Bigozzi U, Maraschio P, Zuffardi O (1989) Evidence for a human mitotic mutant with pleiotropic effect. Ann Hum Genet 53:243-248

Parry DM, Mulvihill JJ, Tsai S, Kaiser-Kupfer MI, Cowan JM (1986) SC phocomelia syndrome, premature centromere separation and congenital cranial nerve paralysis in two siters, one with malignant melanoma. Am J Med Genet 24:653-672

Rudd NL, Teshima IE, Martin RH, Sisken J, Weksberg R (1983) A dominantly inherited cytogenetic anomaly: A possible cell division mutant. Hum Genet 65:117-121

Scheres JMJC, Hustinx TWJ, Madan K, Beltman JD, Lindhout D. A mitotic mutant causing non-disjunction in man. 7th International Congress of Human Genetics, Berlin, 1986; part 1:163

Tolmie JL, Boyd E, Batstone P, Ferguson-Smith ME, AlRoomi L, Connor JM (1988) Siblings with chromosome mosaicism, microcephaly, and growth retardation:the phenotypic expression of a human mitotic mutant? Hum Genet 80:197-200

Warburton D, Anyane-Yeboa K, Taterka P, Yu C, Olsen D (1991) Mosaic variegated aneuploidy with microcephaly: A new human mitotic mutant? Ann Genet 34:287-292 